Georgy I. Rychagov ${ }^{1}$, Vladislav N. Korotaev ${ }^{1 *}$, Aleksey V. Chernov ${ }^{2}$

${ }^{1}$ Faculty of Geography, Moscow State University, Leninskie Gory, 119991, Moscow, Russia

Tel. +7 495 9395469, fax +7 495 9395044, e-mail: river@river.geogr.msu.su

${ }^{2}$ Moscow State Pedagogical University, M. Pirogovskaya, 119991, Moscow, Russia

Tel. +7 499 2450310, fax + 7499 2480162, e-mail: rector.mpgu@ru.net

* Corresponding author

\title{
HISTORY OF FORMATION PALAEODELTAS OF LOWER VOLGA DELTAS
}

\section{ABSTRACT}

The palaeo-Volga River valley existed within the present-day Lower Volga region during the last 600-700 ka. Its lower parts periodically transformed into a long and deep ingressional estuary with the apex location controlled by the amplitude of the Caspian Sea level rise. Between the Early Khvalinian highstand of +50 m and the Early Holocene Mangyshlak lowstand at $-100 \mathrm{~m}$, the apex of the Volga Delta has wandered $700 \mathrm{~km}$ alongstream. The estuarinemarine and alluvial environments in the ingressional estuary in the area between the present-day cities of Volgograd and Astrakhan, were changing throughout the entire Late Pleistocene and Holocene. The associated succession reflects a complex history of the Caspian Sea level oscillations. Only over the last $16 \mathrm{ka}$, there have been six marine (estuarine) phases within the Volga-Akhtuba valley correspondent to the Late Khvalinian and Novocaspian transgressions. The transgressions alternated with regressive phases associated with the dominance of alluvial environments in the Lower Volga valley. There are pronounced traces of three transgressive-regressive phase alternations of the Late Khvalinian and Novocaspian ages in the modern VolgaAkhtuba floodplain topography, that correlate with four generations of ancient floodplain and delta surfaces distinguished in this study. Surfaces of different age generations differ in absolute and relative heights, morphological types of floodplain topography, and present-day vegetation.

KEYWORDS: Volga-Akhtuba valley, palaeodelta, ancient floodplain, bay-head delta

\section{INTRODUCTION}

The Volga-Akhtuba part of the Volga River valley (downstream from the Volgograd city) is geomorphically different from its upstream parts largely occupied by reservoirs. It is characterized by a well-developed wide floodplain, lack of prominent terraces and a symmetric box-like cross-section shape. The adjacent interfluvial areas of the Early Khvalinian marine accumulation plain have a monotonous even surface with dendritic network of flat-bottomed hollows. Within the Late Khvalinian plain areas, aeolian landforms and Baer's mounds are very widespread characteristic landforms.

Long existence of a complex multi-thread channel system of the Lower Volga River determined the formation of two main surface types within the valley bottom that differ in height, location, morphology and age. These clearly distinguished surface types are: i) ancient (central) floodplain and ii) modern floodplains of the Volga River main channel and the Akhtuba branch; they can be further subdivided into different generations of local floodplain surface types. 
The Lower Volga region is located within the Pricaspian tectonic depression - the largest and deepest within the Russian platform with a folding structure of the Karpinskiy anticline in its far southern part. According to geophysical data, pre-Palaeozoic crystalline basement of the depression is found at depths exceeding $15 \mathrm{~km}$. It is fractured into separated blocks at different elevations. The rocks that compose crystalline basement of the depression mainly belong to the Archaean-Proterozoic metamorphic type and are overlain by sedimentary rocks of the Russian platform mantle that consists of undersalt, oversalt, and superficial structural levels. The undersalt structural level is composed of the terrigenous-carbonate rocks of the Late Palaeozoic that form relatively large platform structures broken by fracture dislocations.

Salt domes are the main structural elements of the Pricaspian tectonic depression sedimentary mantle. They were formed as a result of plastic dislocations of enormous masses of the Kungurian stage (Lower Permian) evaporites which initial strata had a thickness exceeding $4 \mathrm{~km}$. The Lower Volga region has large underground salt bodies that form extensive salt ridges or gigantic domes - Enotaevskiy, SolenoZaymichenskiy, etc. The height of salt stocks in such domes reaches 6 to $8 \mathrm{~km}$; they are overlain by Mesozoic or even Neogenic rocks. In the brocken salt domes, such as Inder or Elton, some stocks are open on the surface. The oversalt structural level consists of the Upper Permian and Pleistocene sedimentary rock which is strongly deformed on limbs of salt domes and eroded on top.

The modern valley of the Lower Volga River inherited negative tectonic structures developed at least since the beginning of the Quaternary. The valley section between the Kamyshin and Volgograd cities follows the Volzhsko-Ergeninskiy fracture zone. Its southwestern strike direction coincides with that of the Volgograd flexure and the Bolshoy Volgograd fault. A sharp bend of the valley nearby the Volgograd city - to almost $90^{\circ}$ - is associated with the Akhtubinskiy fault of the southeastern strike direction. The Volga-Akhtuba part of the Lower Volga River valley is formed along the two large linear depression structures. In the northern part, it follows the Arzgirskiy depression (down to the Cherniy Yar settlement), farther southward-theNizhne-Volzhskiy depression. Both of these structures coincide with the deep fracture zone which remained active until the Holocene. Tectonic depressions are superimposed with halokinesis structures such as salt domes Beketovskiy nearby the Volgograd city, Verkhne-Akhtubinskiy at the Akhtuba branch inlet, Kamennoyarskiy, etc. These and other similar active structures cause local deviations of the Lower Volga River valley from its general southern direction and formation of narrowed valley sections. Such influence is often reflected in local characteristics of the Volga River channel morphology and morphometry [Lower Volga River..., 2002; Nikolaev, 1962]. Thus, the Lower Volga River valley formation, geomorphic structure, and channel morphology are largely controlled by tectonic structures and dislocations of the Pricaspian depression crystalline basement. For example, the valley width upstream of Volgograd does not exceed 3-8 km, whereas farther downstream it increases to $30-35 \mathrm{~km}$ with local relatively narrower sections up to 12-15 km wide (Fig. 1).

The upper part of the Paleozoic-Cenozoic sedimentary mantle is mainly composed of unconsolidated Upper Pliocene Quaternary deposits few hundred meters thick. Most of these deposits were formed as marine sediments during the Akchagylian and Apsheronian transgressions. These deposits are dominated by relatively fine sediments (clays and silts) with layers of sand or, less often, marls with basal clays. The Akchagylian and Apsheronian deposits are distinctively characterized by specific macroand microfossil communities.

The sedimentary mantle is topped with a heterogeneous layer of Quaternary deposits 


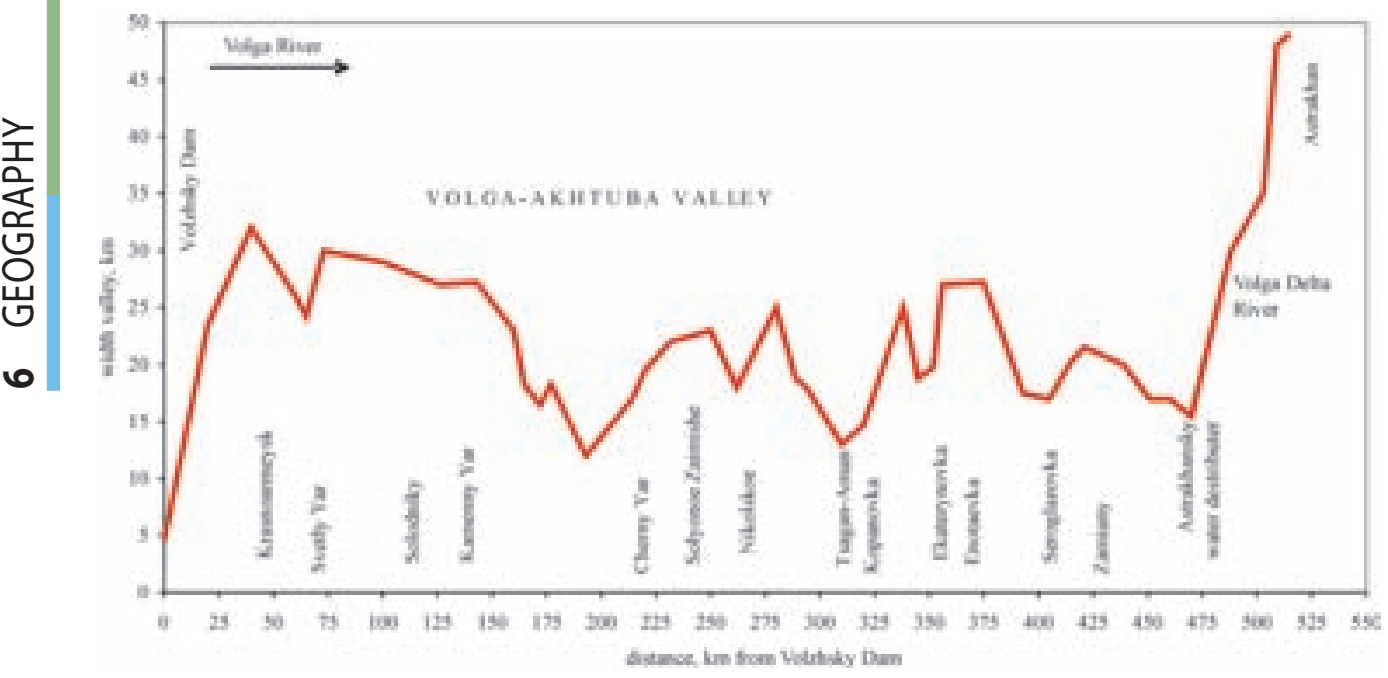

Figure. 1. Width Variability of the Volga-Akhtuba Valley.

exceeding $100 \mathrm{~m}$ in thickness. Within this layer, all major subdivisions of the Quaternary system (Lower, Middle, Upper Pleistocene, and Holocene) can be distinguished". Quaternary deposits are dominated by marine sediments formed during the Baku, Lower and Upper Khazarian, Lower and Upper Khvalinian, and Novocaspian transgressions. Significant part of the geological section is represented by heterogeneous non-marine aquatic sediments, i.e., fluvial, lacustrine, lagoon deposits. Aeolian deposits are the most widespread within sediments of nonaquatic environments, though alluvial fan deposits and some other types are also present. For a long period of geological time, the study area has been a territory of continuous migration of the sea-land interaction zone and the Volga River mouth. Such conditions determine the widespread presence of complex origin sediments:fluvialmarine (deltaic), lacustrine-marine (lagoons, limans, kultuks), and fluvial-lacustrine (oxbow lakes, ilmens). Such deposits often consist of numerous different facies that alternate in both lateral and vertical directions.

The history of the Volga River palaeodeltas formation is closely connected with a

\footnotetext{
I In this paper, authors use the Russian stratigraphic subdivisions. Lower and Middle Pleistocene of the Russian scale correspond to Middle Pleistocene of the International stratigraphic scale.
}

general history of the Lower Volga River valley, and, in particular, the Volga-Akhtuba floodplain formation. This complex and long-term process was primarily controlled by river flow variations, the Caspian Sea level oscillation, and tectonic activity.

The aforementioned history of the development of the Volga River valley suggests that a large river system comparable to the present-day valley existed in the Lower Volga region during the entire Late Cenozoic. This system had a continuously migrating mouth and specific landform complexes that have partly remained prominent up to the present time. Review of previously published data [Goretsky, 1966; Rychagov, 1977; Svitoch et. al., 2000, 2004] allowed us to conclude with a high degree of confidence that the Volga River has been draining into the Caspian Sea at least since the Late Neogene

$\left(N_{2}^{a p}\right)$. The buried Volga palaeovalleys of the Venedy $\left(Q_{1}^{v d}\right)$, Solikamsk $\left(Q_{1}^{s k}\right)$ and Early Krivichi ( $Q_{2}^{k r}$ ) ages have been discovered to the east from the modern Volga valley. The Planforms of these palaeovalleys generally resemble the modern valleys. However, their widths are usually four to five times larger than the widths of modern valleys. This fact suggests that in the past, the palaeo-Volga 
River discharges were significantly greater compared to the present. As it was already stated above, a relatively poor preservation of old alluvial successions in geological sections, does not permit a detailed determination of palaeodelta locations. The task becomes even more difficult when one takes into account their active migration upand downstream the palaeo-Volga valleys following the sea level oscillations.

One of characteristic features of the Volga River mouth dynamics during the Late Pleistocene and Holocene is a poor preservation of palaeodeltas due to sea regressions. Traces of such palaeodeltas were discovered in the Caspian Sea shelf geological structure by M.Yu. Lohin and E.G. Maev [1990]. These paleodeltas are represented by wedge-shaped depositional bodies located at depths of 40-25 m and

dated to the $\left(Q_{3}^{a t}\right)$ and Enotaevsk $\left(Q_{3}^{e n}\right.$ ) ages. Palaeodeltas of later ages, for example those that correlated with the Mangyshlak regression, have not been discovered so far. This may be the consequence of an important geomorphic event correlated with the Late Khvalinian Sea existence formation of the abovementioned specific landforms - sandy ridges that form the basis of the Baer's mounds landscape formation. The Baer's mounds landscape is traced on both sides of the modern Volga-Akhtuba valley from the coastline remnants near the Nikolskoe settlement correlated with maximum stage of the Late Khvalinian transgression, to almost the seaward edge of the modern Volga River delta.

\section{PLEISTOCENE HISTORY OF THE VOLGA RIVER PALAEODELTAS}

First geological traces of the palaeo-Volga valley found in the North Pricaspian region are dated to the Middle Pliocene. Deep coring program discovered a large buried palaeovalley incised 300-500 m into the Cretaceous-Palaeogene bedrock to the east from the modernVolga Rivervalley. It is partially infilled with the gravels, pebbles, sands and clays of the Kushumskaya succession and is traced from western slopes of the Obshiy Syrt upland to the Baskunchak Lake and farther south. All researchers correlate the Kushum succession deposits with the Kinel succession deposits found in similar buried valleys of the Middle Volga region. The ancient drainage network of this region and associated deposits identified as the Kinel succession, were first distinguished and described by A.N. Mazarovich in 1936 and have been by now studied in details. It has been suggested that the Akchagylian (Kinel) age palaeo-Volga delta was located far to the south from the modern delta within the Caspian depression and flowed into a closed water body - the Balakhany Basin.

Numerous evidence of existence of a few palaeo-Volga valley incisions has been found in the Pleistocene deposits of the Lower Volga region. Deep coring carried out by the Hydroproject Institute [3] and geological sections of the modern Volga River valley [Goretsky, 1966] allowed to distinguish the abovementioned deposits of the Venedy, Singil, Lower Krivichi successions, and succession of the Cherniy Yar sands and Atel age deposits. These deposits are represented by a variety of freshwater sediments that contain shells of the freshwater mollusks Lithoglyphus caspicus, L. naticoides, Dreissena polymorpha, Valvata piscinalis, Viviparus duboisianus, V.viviparus, Unio tumidus, U. pictorum, Pisidium amnicum, Sphaerium rivicola, Sph.corneum, Planorbis planorbis etc. The deposits are dominated by material of the active channel alluvial facies, proving the existence of the large palaeo-Volga River valley during the Pleistocene. However, almost no traces of deltas corresponding to these river systems have been found there. On the other hand, within the geological section of the modern Volga delta there are no ancient alluvial deposits older than Atel age sands. Thus, it is possible that the Venedy and Cherniy Yar valley deltas were located upstream from the Astrakhan city.

The palaeo-Volga mouth may have been submerged and had landscapes 
morphologically similar to the modern Dnieper-Bug and Dunay limanes during the Singil (past-Baku) and Early Krivichi (pre-Early Khazarian) ages. The Singil age deposits are widespread within the Lower Volga River valley and Western Pricaspian region. They contain abundant remnants of vegetation (Selaginella selaginoides, Azolla interglacialica, Salviniapatens) and freshwater mollusks (Unio cf. pictorum, Viviparus duboisianus, Pisidium amnicum, Sphaeriumrivicola, Valvatapiscinalis, Planorbis planorbis, Theodoxus sp., Dreissena polymorpha etc.). These data suggest that the formation of these deposits occurred under conditions of slow sedimentation in tranquil waters of vast stagnant or semiflowing water bodies. The Early Krivichi age alluvial sands overlay the Singil age deposits, proving a deepening regression of the Caspian Sea during that period. There is no reliable information on the spatial pattern of the Krivichi age drainage network in the Lower Volga region. As suggested by G.I. Goretskiy [1966], the palaeodelta of that time was located to the west from the modern Volga River valley, near the presentday Ergeni upland. However, most likely the location of the Krivichi age delta during the deep pre-Khazarian regression of the Caspian Sea was at the southern margin of the North Caspian.

In the Volga River valley section between the Raigorod and Nikolskoe settlement, polyfacial alluvial deposits of the Cherniy Yar succession are widespread. They overlie the erosional unconformity of the Lower Khazarian or Singil deposits. The stratotype of the Cherniy Yar succession has been described in the Cherniy Yar - Nizhnee Zaimishe geological section. Lithologically it is mainly represented by active cross-stratified channel sands, containing numerous bone remnants of large mammals of the Khazarian palaeofauna. Its age is usually attributed to the middle part of the Middle Pleistocene. The stratigraphic position and altitude of the Cherniy Yar succession sands, characteristic fauna remnants, and lithological properties suggest that these deposits were formed in a large river channel during the middle-end of the Middle Pleistocene. The palaeoriver mean low-water level coincided with that of the modern Volga River, or was slightly higher.

Another generation of the palaeo-Volga River delta existed in the Lower Volga region during the Middle Pleistocene. This statement is supported by analysis of the geological section near the Seroglazovka settlement, where alluvial sands of the Cherniy Yar succession change laterally into deltaic deposits correlated with the Late Khazarian Sea level (deposits with Didacna surachanica). The Cherniy Yar and Singil succession alluvial and deltaic deposits of the palaeo-Volga River are correlated with relatively low-amplitude "warm" transgressions of the Caspian Sea (the Late Khazarian and Urundzhik, respectively). These deposits are characterized by diverse palaeontological findings, including freshwater mollusk shells (Unio pictorum, Viviparus duboisianus, Valvata piscinalis, Lithoglyphus cf. naticoides, Bithynia tentaculata, Planorbis planorbis, Theodoxus sp., Dreissena polymorpha, etc.), which proves the presence of clear warm flowing water bodies within palaeovalleys at that time.

The existence of the Atel age palaeoVolga valley is proven by delta deposits of the same age discovered along the boundary between the Northern and Southern Caspian Sea. Later, during the Early Khvalinian transgression maximum, the sea covered the entire territory of the Pricaspian lowland to the north from the Kamyshin city. The submerged palaeoVolga valley of that period was represented by a narrow and long estuary stretched to approximately $500 \mathrm{~km}$, as far upstream as to the Samarskaya Luka. It was filled with relatively cold slightly saline waters. The depth of the estuary exceeded $40 \mathrm{~m}$. The so-called "chocolate" clays with rare molluscs of the slightly brackish type fauna (Monodacna caspia, Hypanis plicatus) were deposited in its relatively stagnant waters, mainly from suspended sediment delivered 
by the river. It is believed that the coarser material represented by the palaeo-Volga bedload sediment was deposited farther to the north.

The Early Khvalinian Sea regression was marked by high-amplitude sea-level fluctuations that resulted in the formation of the stadial terraces at altitudes of 20-22 m, $14-16 \mathrm{~m}$ and $4-6 \mathrm{~m}$. Following the retreating sea, the palaeo-Volga River inherited not only its pre-Khvalinian valley. The Sarpinskaya and Davan depressions that formed at the same time are still prominent in the modern topography.

During the Enotaevsk regression, the Lower Khvalinian deposits were subject to intensive erosion. Incision took place both within the Pricaspian lowland and in the land areas to the south which are, at present, occupied by the Caspian Sea. The period of erosion is evident from the sharp and uneven upper boundary of the "chocolate" clays observed in cores taken from the present-day Caspian Sea bottom. Erosional dissection of the

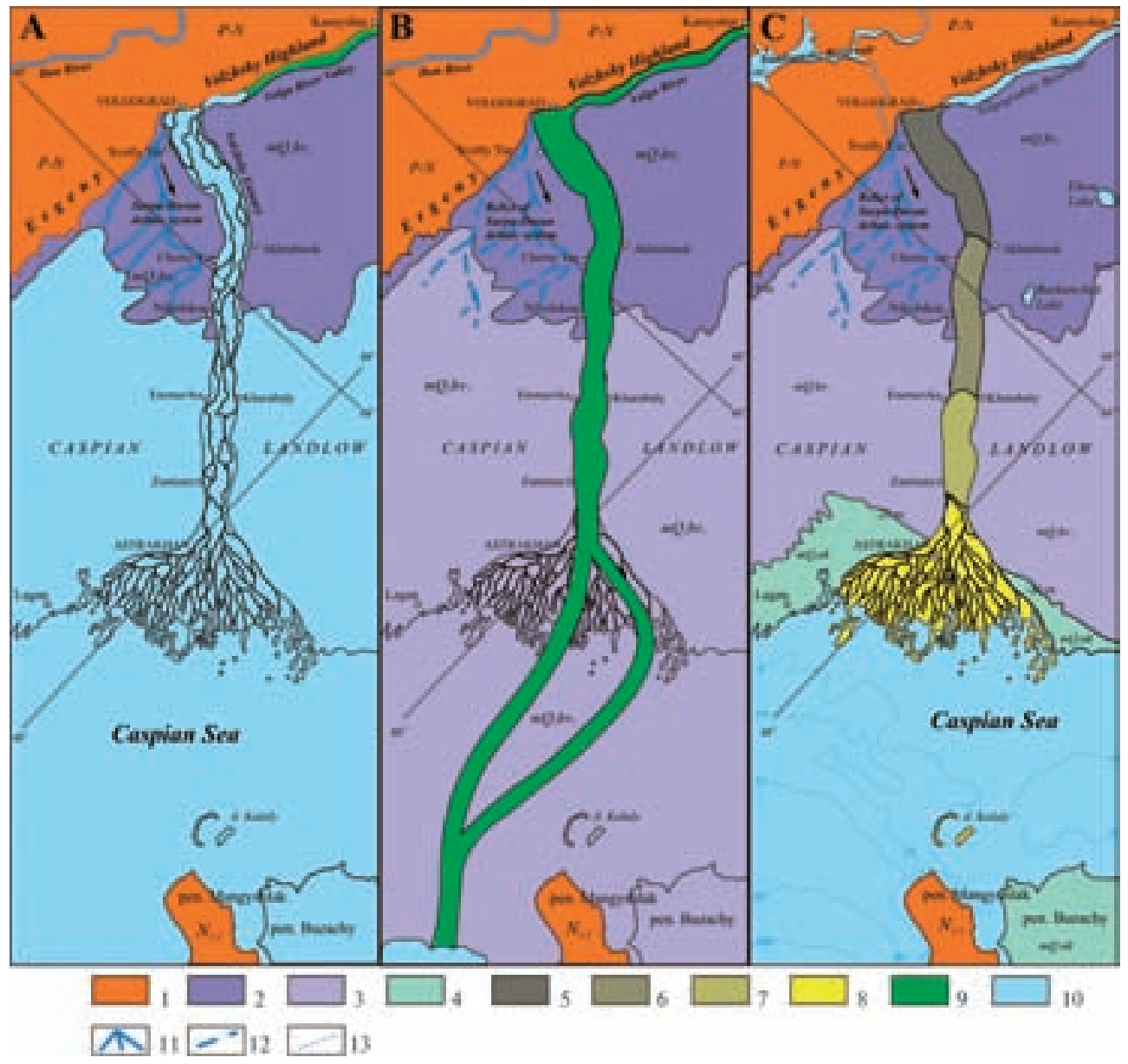

Figure 2. The history of the Lower Volga palaeodeltas formation and their position in the VolgaAkhtuba Valley. A - Maximum stage of the Late Khvalinian transgression (0 m BSL), B - Maximum stage of the Mangyshlak regression (-100 m BSL (i.e, Baltic System Level). C - Recent stage of formation the Volga Delta. 1 - Highland accumulative-denudation, 2 - Marine accumulative plane of Early Khvalinian, 3 - Marine accumulative plane of Late Khvalinian, 4 - Marine accumulative plane of Novocaspian, 5 - Floodplane Makhachkala of Late Khvalinian (17-12 ka, -3-(-9) m BSL), 6 - Floodplane Turali of Novocaspian (9-5 ka, -9-(-18) m BSL), 7 - Floodplane Ulluchay of Novocaspian (4-1,5 ka, -18-(-23) m BSL), 8 - Recent Volga Delta and marine islands (less 1 ka, -25-(-27) m BSL), 9 - Volga Channel of the

Late Khvalinian, 10 - water surface, 11 - river systems, 12 - relict river systems, 13 - isobaths. 
Early Khvalyn plain during the Enotaevsk regression determined the complicated coastline configuration of the Late Khvalinian Sea.

During the Late Khvalinian transgression maximum, there was a funnel-shaped bay in the palaeo-Caspian Sea at the Sarpa-Davan depression mouth (Fig. 2-A). The Ural River flowed into the estuary. Bays also existed in the mouths of the Bolshoy and Maliy Uzen, Uil, Sagiz, and Emba rivers. In the Volga River valley, the Late Khvalinian Sea bay apical part was located between the presentday Kamyshin and Volgograd cities. Such a planform of the sea coastline determined specific hydrodynamic conditions in the coastal zone. The interaction of oppositely directed hydraulic and surge currents favoured the formation of accumulative underwater landforms in the coastal zone of the Late Khvalinian Sea. These landforms were similar to sand ridges widespread on shelves of many present-day seas. Another condition necessary for the development of such landforms was a substantial amount of sediment delivered by rivers as a result of erosion of the older marine deposits. Such sandy ridges commonly develop at bay and gulf outlets, along open coastlines with significant tidal amplitude, in shallow marginal seas, and in river deltas and estuaries. We suggest that these depositional landforms (i.e., sandy ridges) formed a basis for the modern Baer's mounds landscape topography. Despite certain discrepancies in the Baer's mounds distribution areas distinguished by different authors, one fact is undisputable: all such landforms are located within the territory that was subject to the Late Khvalinian transgression. Moreover, they are mostly associated with the zones of palaeodeltas and estuaries of the rivers flowing into the Late Khvalinian Sea [Kroonenberg et. Al., 1997, 2008; Rychagov, 1977; Varushchenko et. Al., 1987].

The Early Khvalinian marine plain experienced substantial relief transformations during the Late Khvalinian Sea transgression. The Sarpinskaya depression was once again filled with a river flow. The interfluves between the Volga valley and Sarpinskaya depression and areas to the east from the present-day VolgaAkhtuba valley were dissected by a system of incised deltas. The latter are still prominent in the modern relief. Similarly to the Early Khvalinian period, the Late Khvalinian Sea retreat was interrupted by relatively limited transgressive phases. These events resulted in formation of coastlines which remnants can be traced on altitudes of -5-(-6) $\mathrm{m}$ (Kuma phase), -11-(-12) m (Sartassk phase), -16-(-18) m (Dagestan phase), and -30-(-32) m (Samur phase).

\section{HOLOCENE BAY-HEAD PALAEODELTAS OF THE VOLGA-AKHTUBA VALLEY}

The beginning of the Late Khvalinian Sea regression corresponds to the formation of the first terrace (Sarpa terrace, 14-17 ka) that currently exists in the modern Volga River valley (Fig. 2-B). Although this terrace is not prominent in the modern topography, its fragments can be observed near the Vyazovka and Staritsa settlements on the right side of the Volga-Akhtuba, as well as near the Leninsk city, Sokrutovka settlement, and in some other locations on the left side of the valley. It is probable that the Lower Volga River channel dichotomy formation also took place at that period of time. Two quasi-independent watercourses (the Volga main channel and Akhtuba branch) have most likely inherited two main branches of the Late Khvalinian estuary infill (Volgograd) delta. The larger and most active right branch gave rise to the modern Volga River main channel, while the left branch that followed the Akhtubinskiy fault structure, later developed into the Akhtuba branch. The geological structure of the VolgaAkhtuba valley (closely connected with the Volgogradskiy fault and the VerkhneAkhtubinskaya anticline) is an example of tectonic control over the valley's direction. The tectonic structure has also determined the bifurcation of the Volga River channel, specifically, the anticline represented by a crest-like fold of the Maikop age clays [Goretsky, 1966]. Within ancient deltas 
(Akhtubinskaya and younger), these two main branches remained closely interconnected by numerous secondary channels. However, as deltas gradually migrated downstream following the retreating sea, the branches became more and more separated. This process remained relatively continuous along many stages of the Astrakhan-Volgograd estuary infill and eventually gave rise to the modern anastomosing pattern of the Lower Volga River channel. The Volga-Akhtuba floodplain was formed by geomorphic activity of both the Volga River main channel and the Akhtuba branch.

An analysis of available aerial and satellite images, and topographic and geological data allowed us to reconstruct the last stages of the Astrakhan-Volgograd ingressional estuary infill by the Volga River sediment, which took place during the Late Pleistocene and Holocene since the Late Khvalinian transgression. The geomorphological structure of the Volga-Akhtuba floodplain is not uniform. As discussed above, it consists of: i) the modern floodplains of the Volga main channel and the Akhtuba branch; and ii) the ancient floodplain represented by sections of four different generations consecutively alternating downstream (Fig. 2-C). The modern floodplain is stretched along the Volga and Akhtuba channels. It is characterized by depression-island (the Volga main channel) or segmented-ridge (the Akhtuba channel) primary topography. Differentgenerations oftheancientfloodplain located between the Volga main channel and the Akhtuba branch occupy more than $80 \%$ of the entire Volga-Akhtuba floodplain area. These elements can be distinguished by their structure and morphology. Both modern and ancient floodplain surfaces have similar relative elevations over the mean lowwater level. However, it must be noted that overlain levees of the modern floodplain are commonly about $1 \mathrm{~m}$ higher than surfaces of ancient floodplain generations [Bolikhovskaya, 1990; Estuarine-deltaic systems of Russia and China..., 2007; Geology of the Volga River Delta, 1951; Korotaev, and Chernov, 2000, 2001; Li C.X. et. al., 2004; Lower Volga River..., 2002; Nikolaev, 1962].

Alternation of the estuarine-marine and alluvial environments has taken place in the

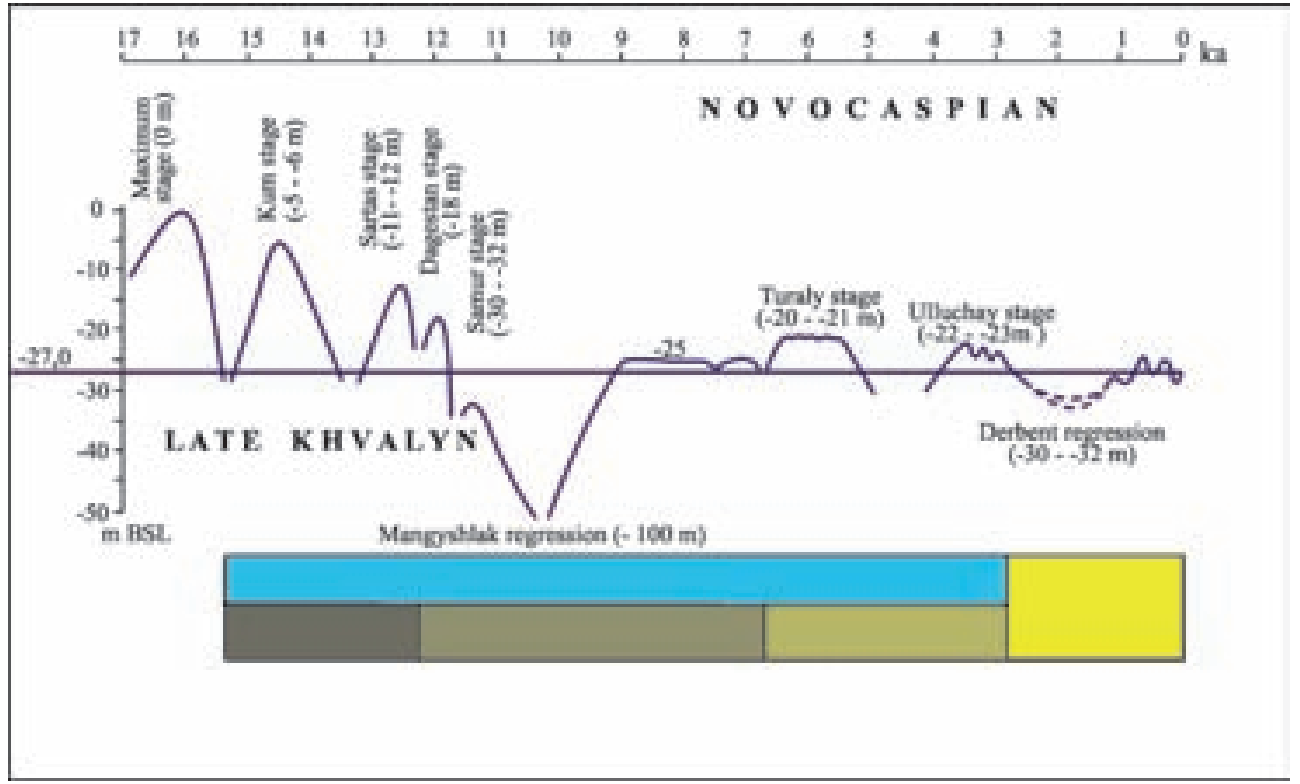

Figure 3. The diagram of changes in the Caspian Sea-level during Late Pleistocene - Holocene and the main period of formation of the Volga-Akhtuba floodplain [after G.I. Ruchagov, 1977] 
ingressional estuary between the presentday Volgograd and Astrakhan cities during the entire Late Pleistocene and Holocene. This succession reflected a complex history of the Caspian Sea level oscillations. Only over the last $16 \mathrm{ka}$, there were six marine (estuarine) phases within the Volga-Akhtuba valley correspondent to transgressive phases of the Late Khvalinian and Novocaspian ages (Fig. 3). These events alternated with regressive phases associated with the dominance of alluvial environments in the Lower Volga valley.

The Late Khvalinian transgression was followed by the Mangyshlak regression when the sea level retreated to about -100 m BSL. The Volga River delta was then located at the boundary between the northern and central parts of the modern Caspian Sea. As a result, the Volga River channel incised deeply and partly eroded the Khvalinian transgression deposits forming two main channels at the location of the present-day Volga River delta. The entire post-Khvalinian time, Volga River discharge was passing through these two branches.

The beginning of the Novocaspian transgression was accompanied with the depositional infill of deep Volga River incisions formed during the Mangyshlak regression and simultaneous erosion of the Baer's mounds by wave action. The Caspian Sea level grew to $-25 \mathrm{~m}$ BSL during the first phase of the Novocaspian transgression and further reached $-20 \mathrm{~m}$ BSL during the maximum phase (the Turali stage). A relatively small marine bay existed in the Volga River valley to the north from the present-day location of the Astrakhan City during the Turali stage of the Novocaspian transgression. At the same time, the Novocaspian transgression deposits filled the depressions between the Baer's mounds and the Mangyshlak regression incisions at the present location of the Volga River delta downstream from the Astrakhan City. The formation of the Zamyanskiy section of the Volga-Akhtuba floodplain and the bifurcation of the main channel at the present outlet of the Buzan branch took place at that time. The Turali stage of the Novocaspian transgression was followed by a relatively prolonged but limited in amplitude regression. During that period, both the Volga main channel and the Akhtuba branch returned into the incisions formed during the Mangyshlak regression.

The second stage of the modern Volga River delta formation and its geomorphic evolution was associated with the Ulluchay phase of the Novocaspian transgression (3,0-2,5 ka BP) when the Caspian Sea level rose up to -23-(-24) $\mathrm{m} \mathrm{BSL}$ and Active deposition of the kultuk-ilmen (lacustrinemarine and fluvial-lacustrine) sediment facies took place. Currently, these deposits are widespread over the entire area of the modern Volga River delta. Predominantly fine silt-clay sediment composition and numerous findings of freshwater mollusks remnants (Planorbis planorbis, Unio tumidus, Valvata piscinalis, Dreissena polymorpha) indicate that sedimentation occurred mainly in fresh (or less frequently brackish) stagnant water bodies with calm and stable sedimentary conditions. Lithological characteristics of the kultuk-ilmen deposits are substantially different from those of the avandelta (distal part of a delta submerged by shallow sea waters up to $15 \mathrm{~m}$ deep) deposits. However, no prominent traces of sedimentation discontinuity are observed between these parts of the delta. It can therefore be concluded that the regression separating the two peaks of the Novocaspian transgression was limited in amplitude and did not cause significant incision of the deltaic watercourses. The main branches of the present-day VolgaAkhtuba valley - the Volga main channel, and Buzan, Bushma, Kigach, and Akhtuba have already existed in the delta upper part during that period of time. They inherited existing incisions and separated the deltaic plain into large lowland islands. Thus, the second stage of the Novocaspian transgression was characterized by the continuing development of the estuary 
infilling delta and the onset of the formation of advancing delta.

The Ulluchay stage of the multiphase Novocaspian transgression was followed by the Derbent regression when the Caspian Sea level fell to $-32 \mathrm{~m} \mathrm{BSL}$. This event triggered a new stage of the Volga River delta evolution, specifically, the onset of the advancing delta formation beyond the area of Baer's mounds development. Later on, insignificant sea level fluctuations caused a number of changes of the delta planform and patterns of its branches. Nevertheless, traces of two large palaeo-branches occupying the main incisions formed during the Mangyshlak regression remained prominent in the Volga River delta topography until the early 20th century as the Sinee Mortso Bay (at the ancient Buzan branch location) and the Zelenginskiy Bay (at the ancient Bushma branch and the Belinskiy bank location). After the Derbent regression the Caspian Sea level has never risen above $-25 \mathrm{~m}$ BS.

The modern stage of the Volga River delta evolution generally coincides with the history of the regional geomorphological development that has been marked by greater contribution of fluvial processes that formed channel-floodplain landform complexes (floodplain, channel, natural levees, etc.). They were controlled by hydrological regime which played a dominant role in the delta morphology transformations. As a result, the alluvial-deltaic sedimentation regime now prevails over most of the delta, while the kultuk-ilmen (lacustrinemarine and fluvial-lacustrine) and avandelta sedimentation regimes are limited to only distal parts of the delta.

\section{CONCLUSION}

There is sufficient evidence that the palaeo-Volga River valley existed within the present-day Lower Volga region during the last 600-700 ka. Its lower parts were periodically transforming into a long and deep ingressional estuary with the apex location controlled by the amplitude of the Caspian Sea level rise.
There are pronounced traces of four transgressive-regressive phases of the Late Khvalinian and Novocaspian ages in the modern Volga-Akhtuba floodplain topography that correlate with three generations of ancient floodplain and delta surface types identified in this study. The surfaces of different age generations vary in absolute and relative heights, morphological type of floodplain topography, and modern vegetation.

During the transgressive phases, the lower parts of the valley located below the arisen sea level became filled with slightly saline waters, flowing slowly seaward. Relatively gradual and continuous sedimentation occurred on the estuary bottom under such limane-like conditions. This finer sediment became settled by marine fauna. During the regressive phases, the palaeoVolga followed the falling sea level, incising into previously deposited layers of marine and lagoon sediment. This sediment was later reworked and redeposited as alluvial material usually separated into active channel and floodplain facies during floodplain formation. The depth of the palaeo-Volga channel incision during the Caspian Sea regressions did not exceed 20-25 m. A very shallow coastal zone with extremely low seaward gradients did not favor the development of deeper incisions. Under such conditions, the base level drop cannot be followed by a substantial channel incision. That is why only remnants of the oldest alluvial successions lying deeper than 20-25 m under the present-day Volga River mean low-water level, are preserved in geological sections of the modern Volga-Akhtuba floodplain. These remnants are overlain by the Holocene alluvial sediment which underwent multiple reworking during the past Caspian Sea regressions.

\section{ACKNOWLEDGEMENTS}

This research work was supported by the Russian Foundation for Fundamental Research (Grant no. 07-05-00525). 


\section{REFERENCES}

1. Bolikhovskaya, N.S. (1990). Palaeoindication of the Lower Volga Region landscape evolution over the last 10 thousand years. In: The Caspian Sea-Questions of geology and geomorphology. Moscow, Nauka Publ., pp. 52-68 (in Russian).

2. Estuarine-deltaic systems of Russia and China: hydrological-morphological procceses, geomorphology and predication of evolution. (2007). Moscow, GEOS Publ., 445 p. (in Russian).

3. Geology of the Volga River Delta. (1951). Edited by M.V. Klenova. The GOIN Proceedings, vol. 18(30). Leningrad, Gidrometeoizdat Publ., 395 p. (in Russian).

4. Geology of region Volga - Don Canal. (1960). Edited by V.D. Galaktionov. MoscowLeningrad, State Power Supply Sources. Publ., 416 p. (in Russian).

5. Goretsky, G.I. (1966). The Volga River Valley formation in Lower and Middle Pleistocene. Moscow, Nauka Publ., 412 p. (in Russian).

6. Korotaev, V.N., and Chernov, A.V. (2000). Morphology and dynamics of the Volga-Akhtuba floodplain. Geomorfologiya, 3, pp. 61-69 (in Russian).

7. Korotaev, V.N., and Chernov, A.V. (2001). Formation of the Volga-Akhtuba valley floodplain and the Volga River palaeodeltas during the late Pleistocene and Holocene. In: Soil erosion and river channel processes, vol. 13. Moscow, Moscow State University Publ., pp. 229-240 (in Russian).

8. Kroonenberg S.B., Rusakov G.V., Svitoch A.A. (1997). The wandering of the Volga delta: a response to rapid Caspian Sea-level change. J. Sedimentary Geology, 107, pp. 189-209.

9. Kroonenberg S.B., Kasimov N.S., Lychagin M.Yu. (2008). The Caspian Sea, a natural laboratory for sea-level change. J. Geography Environment sustainability, No 01. pp. 22-37.

10. Li C.X., Ivanov V.V., Korotaev V., Yang S.Y., Chalov R., and Liu S. G. (2004). Development of the Volga Delta in Response to Caspian Sea-Level Fluctuation during Last 100 Year. J. of Coastal Research, 20 (1), pp. 152-165.

11. Lokhin, M.Yu., and Maev, E.G. (1990). The Middle Pleistocene age palaeodeltas on shelf of the Middle Caspian Sea northern part. Vestnik Moscow State University, Geography, vol. 3, pp. 34-39 (in Russian).

12. Lower Volga River: geomorphology, palaeogeography and channel morphodynamics. (2002). Ed. by G.I. Rychagov and V.N. Korotaev. Moscow, 'GEOS Publ., 241 p. (in Russian).

13. Nikolaev, V.A. (1962). Geological evolution, relief and alluvial deposits. In: Nature and agriculture of the Volga-Akhtuba Valley and the Volga River Delta. Moscow, Moscow State University Publ., pp. 11-56 (in Russian).

14. Rychagov, G.I. (1977). The Caspian Sea Pleistocene history. Moscow, Moscow State University Publ., 268 p. (in Russian). 
15. Svitoch, A.A., and Badukova E.N. (2004). Buried valles of Lower Volga. Geomorfologiya, 2, pp. 55-68 (in Russian).

16. Svitoch, A.A., and Yanina, T.A. (1994). Structure and development of the Volga River Delta. Geomorfologiya, 4, pp. 11-24 (in Russian).

17. Varushchenko, S.I., Varushchenko, A.I., and Klige, R.K. (1987). Changes of the Caspian Sea and enclosed water bodies hydrological regime during the palaeo-times. Moscow, Nauka Publ., 239 p. (in Russian).

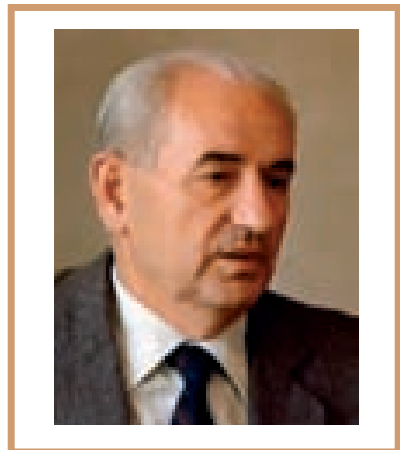

RYCHAGOV, Georgy I. is Doctor of Geography, full Professor, Department of Geomorphology and Paleogeography, Faculty of Geography, M.V. Lomonosov Moscow State University. Dr. Rychagov has the honorary title "Honored Worker of Science of the Russian Federation." He is a well know expert in Russia and around the world in the fields of paleogeography and geomorphology of the Caspian Basin. He has made a valuable contribution to the research of the development and forecast of the endorheic reservoir the Caspian Sea. Dr. Rychagov has taught a core course "Geomorphology with the Basics of Geology". He has published nearly 150 scientific works, including 11 monographs and 11 textbooks and tutorials.

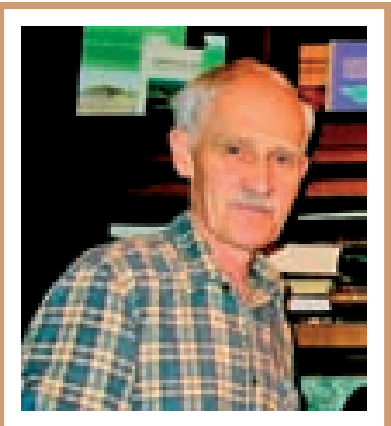

KOROTAEV, Vladislav N. is Doctor of Geography, Leading Research Scientist, Scientific Research Laboratory of Soil Erosion and River Channel Processes, Faculty of Geography, M.V. Lomonosov Moscow State University. He is a prominent expert in the field of geomorphology of coastal zone and river deltas. He has created and successfully developed new branch of science, i.e. dynamic geomorphology of river deltas, which covers sediments accumulation, geochronology of deltas sediments, structure, genesis and development of relief and delta plains, and principles of regulation of river mouths. He has published nearly 150 scientific works, including 21 monographs, 3 thematic maps and 2 atlases.

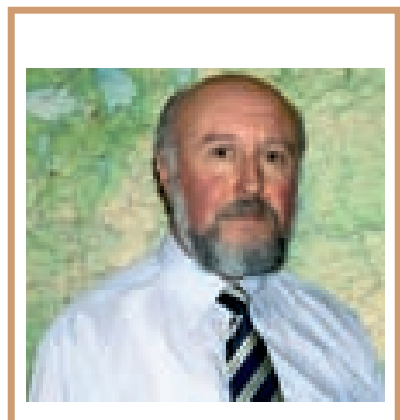

CHERNOV, Aleksey V. is Doctor of Geography, Head of Department of Physical Geography and Geoecology, Moscow State Pedagogical University. He is a leading expert in the field of formation and development of river floodplains, cartography and regionalization of territories based on riverchannel processes and ecological conditions of river channels, floodplains, and river valleys. He has published 170 scientific works, including 3 thematic maps and 6 monographs. 